\title{
The Effect of Corporate Governance, Corporate Financing Decision and Ownership Structure on Firm Performance: A Panel Data Approach from Tehran Stock Exchange
}

\author{
Nassim Shah Moradi ${ }^{1}$, Mahmood Moein Aldin ${ }^{1}$, Forough Heyrani ${ }^{1} \&$ Mohsen Iranmahd ${ }^{1}$ \\ ${ }^{1}$ Department of accounting, Yazd Branch, Islamic Azad University, Yazd, Iran \\ Correspondence: Nassim Shah Moradi, Department of accounting, Yazd Branch, Islamic Azad University, Yazd, \\ Iran. Tel: 98-913-352-4398. E-mail: Shnassim@yahoo.com
}

Received: April 12, 2012

Accepted: April 26, 2012

Published: June 1, 2012

doi:10.5539/ijef.v4n6p86

URL: http://dx.doi.org/10.5539/ijef.v4n6p86

\begin{abstract}
Capital structure, dividend policy and corporate governance are today significantly influencing academic debates on firm's value, while they can increase profitability and shareholder's value in long term. This paper seeks to investigate the affects of corporate governance mechanisms and financing activities on firms' performance. A sample of 84 firms listed on Tehran Stock Exchange for a period of five years from 2007 to 2011 was selected. These firms were chosen by employing random classified sampling. The study used Return on Investment (ROI) and Tobin's Q as proxies for performance and developed multiple and single regression models, mean tests and correlation coefficients to test the hypotheses. The findings reveal that corporate governance, financing decisions and capital structures are affected by firms' performance.
\end{abstract}

Keywords: corporate governance, ownership structure, agency theory, financing decision, performance

\section{Introduction}

Capital market is an essential component of economics because it begins the stagnant funds and is also considered as a proxy for economic growth of countries. Therefore considering this market and the fundamental decision making basis are necessary. It is obvious that profit maximization is the main purpose of managers which generally aim at. Investors, internal employees and society at a large scale are the beneficiaries of successfulness in creating value of firms. Given that Performance evaluation in decision making is considered as a very significant subject in financial economics, it seems necessary for financial and economical measures to be evaluated.

The conflict of interest between owners and managers has caused performance evaluation of managers and firms to become an important aspect which is largely considered by different parties such as creditors, owners, government and even managers (Jensen \& McLin, 1976).

Conflict of interest among stakeholders is one of the most important and influential factors because firms confront different decisions which include paying dividends or repaying debts and financing new investments. There is tight relationship among earnings per share, investments and finance, therefore, making suitable decisions and policies in accordance with economic situation, industry and a given firm leads to better performance and finally increased value of firms. Corporate governance and topics related to stakeholders (managers, employees, customers, executive managers, board of directors and shareholders) are imperative fields in developing countries like Iran. Financial performance of firms has a direct relationship with corporate governance. More qualified managers implement more effective corporate governance and pay more attention to their stakeholders which at last causes more return.

Managers are expected to be successful in dealing with growth, on time repaying of accruals, creating value for shareholders, managing risk, and developing corporations' purposes. When the performance of firms is affected by corporate governance structure, then shareholders need more controls to be performed on managers that aim to reduce the consequences of conflict of interest resulting from agency costs on the profitability of firms .The existing corporate governance system deals with several internal factors such as ownership structure of firms, economic situation, legal framework, public and cultural policies. Ownership structure and legal frameworks are the most important factors between all. Any change in components and ownership structure results in a change in governance path and their performance and at last leads to an increase or decrease in agency costs. 
Investigating the quality and quantity of corporate governance and its affects on firms' performance can be useful to support investors and help financial analyzers since in recent years there are satisfactory changes happened in Iran in consistent with the privatization law enacted. This study has been designed and carried out to examine the affects of corporate governance and financing decisions on financial and economic performance of firms.

\section{Literature Review}

Ozer and Yamak (2004) tested whether the level of market control by shareholders in a diversified stock ownership lead to a difference in the firms' performance. Their findings demonstrated that the relationship between ownership structure and firm's performance is only significant for return on assets and return on equity; while return on sale and interest rate have no significant relationship with shareholders combination. Lefort (2007) documented that an increase in the ratio of the non executive members of board of directors results in increased firm value. When the ratio of non executive members and professional ones are analyzed separately then it is only the ratio of the non executive members that affects firm value.

Liu and Lu (2007) employed the percentage of shares in hand of senior executive managers, level of independence between board of directors, regulatory environment and institutional situation on corporate governance to measure the relationship between earnings management and corporate governance. Their results showed that the degree of earnings management is significantly related to measurement proxies of corporate governance. In a similar study Imam and Malek (2007) examined the relationship among ownership structure and firms' performance and dividend policy. Their research sample consisted of 201 firms for a three years period covering 2001-2003. Their results demonstrated that corporate ownership has a positive and significant effect on the firm's performance, while dividends policy is negatively affected by management ownership concentration. Emran (2008) argued that the ownership in developing countries belong with a small group of specific people, e.g., entities or government and this has provided a situation in which there is no major conflict between managers and stakeholders. In another study Siregar and Utama (2008) found evidence that institutional ownership, size of the firm and corporate governance approach do not influence on the type of earnings management. They had documented no evidence based on the effect of corporate governance variables (including auditing quality, directors' independence and auditing commission) on the type of earnings management.

Al Mutari (2009) examined 80 firms listed on Kuwait Stock Exchange in a 9 year period including 2000-2008. The results of their study showed that the type of shareholders influences on firms' value, while public and individual ownership have a negative and significant impact on the firms' value. In addition to capital structure, dividends policy is also another factor directly affecting firm's value, he declared. Al Najar (2009) investigated the relationship between ownership structure and corporate governance among non-financial firms in Jordan. They found that institutional investors care about diverse factors such as capital structure, trade risk, profitability, property structure, asset liquidity and size of the firm in their decisions around investments. Generally they prefer investments in service companies in comparison with manufacturing firms. He argues that there is no significant relationship evidenced between dividends policy and institutional investors. Guedhami, Pittman\&Saffar (2009) examined the ownership structure in accordance with the selection of auditing firms after which they controlled the factors relating to size, financial leverage, and inventories to total assets, sales growth and gross domestic product. They showed that public and foreign ownership is negatively related to the selection of Big-4 companies. Block et al (2010) studied corporate governance and market value of firms in Korea for a period of 1998 to 2004 and they found that firms with better governance have less capital expenditure while sales growth is low and investment is more sensitive to profitability. The results also showed that profitability is sensitive to more growth opportunities. Lanor and Almarzoughi (2011) used 35 French-listed companies in 2002 to 2005 and examined their intuitional ownership and their performance. The results indicate that there is a significant reverse relationship between these two indices measured by Tobin's Q. Setayesh et al (2010) found that corporate governance affects on earnings smoothing. They included 383 firms listed on Tehran Stock Exchange for a period of years covering 2003-2009. Multi logistic regression was employed and it was found that different groups of corporate governance have no consistent affect on industrial groups while the independence of board of directors does not influence on earnings smoothing.

\section{Statistical Population, Sample and Methodology}

We have used all firms listed on Tehran Stock Exchange with the following characteristics for a period covering 2006-2010:

They shouldn't have been classified as financial intermediaries, banks, insurance companies and investment companies.

Their fiscal year should have been in consistent with the calendar year and there should be no change in their fiscal year for those years under investigation. 
There should have been data related to institutional shareholders with more than 5\% ownership in the given period.

Finally, there were 384 firms and 84 firms constituted our sample.

\subsection{Methodology}

The present paper is a descriptive study and uses mean comparison tests along with simple and multiple regression models in order to examine the relationship between variables.

\subsection{Variable Calculations}

Firms' performance is the dependent variable chosen to measure Return on Investments (ROI) and Tobin's Q as follows:

\section{TOBIN 'S Q=MV/BV-DEBT}

Where in it;

$M V=$ Market Value of firms (number of shares multiplied by their price at the end of the period) and

$\mathrm{BV}=$ Book value of assets (Mahdavi \& Heyderi, 2006)

In addition Return on Investments is calculated as follows:

\section{ROI $=$ Net Income/Average Investments}

Independent variables of the study include corporate governance, financing decisions and ownership structure which are explained below.

Corporate governance mechanisms are measured by 4 components as follows:

1 - Internal auditing is a dummy variable that is equal to 1 when there is an internal auditor and 0 otherwise.

2- Non executive members to total members of board of directors which is measured by dividing the mentioned items.

3-The ownership percentage of institutional investors that include the percentage of shares owned by insurance companies, investment corporate and banks as defined by Stock Exchange Committee.

4-CEO Duality is a dummy variable that takes the value of 1 if the CEO is also the chairman of the board of directors and 0 otherwise.

Financing decisions are also measured by capital structure and dividend policy. Capital structure is calculated by dividing total debts to total assets followed by dividend policy which is the result of dividing DPS (Dividends per Share) to the current price of each share. Ownership structure is another dummy variable which takes the value of 1 if there is an institutional investor and 0 otherwise.

\subsection{Hypothesis Development}

H1-Corporate governance influences on firm's performance.

H1-1- The ratio of non-executive members influences on firm's performance.

H1-2- The percentage of institutional investors influences on firm's performance.

H1-3- CEO Duality influences on firm's performance.

H2- Financing decisions influence on firm's performance

H2-1-Capital structure influences on firm's performance.

H2-2- Dividend policy influences on firm's performance.

H2-3-Ownership structure influences on firm's performance.

3.4 Data Analysis

\subsubsection{Descriptive Statistics}

Table1. Shows the Mean and Standard Deviation of variables described above. 
Table 1. Descriptive Statistics

\begin{tabular}{llllll}
\hline & $\mathrm{N}$ & Minimum & Maximum & Mean & Std. Deviation \\
\hline Assets & 269 & 18425000000 & 354528035000000 & 5694419399146 & 31164361550369 \\
Liabilities & 269 & 6362000000 & 331379476000000 & 4454616597225 & 28524671462208 \\
Net income & 269 & 347000000 & 13893793000000 & 394362329040 & 1466549418596 \\
Market value & 269 & 210 & 25995 & 4720 & 4577 \\
Number of shares at the end of fiscal year & 269 & 5000000 & 6300000000 & 333717629 & 871403764 \\
Market Value at the end of fiscal year & 269 & 25479700 & 41961600000000 & 1063043613536 & 3288987019751 \\
DPS & 231 & 0 & 5840 & 553 & 742 \\
Institutional stockholders & 241 & .00 & 100.00 & 31.88 & 31.27 \\
ROI & 269 & .00 & .39 & .12 & .08 \\
QTobin's & 269 & .34 & 3.39 & .32 & .56 \\
Capital Structure & 269 & .10 & 1.44 & .18 & .20 \\
Dividends policy & 231 & .00 & 3.48 & & .40 \\
& & & & & \\
Valid N (listwise) & 217 & & & & \\
\hline
\end{tabular}

Descriptions: Table 1 shows the Mean and Standard Deviation of variables described above.

We have initially calculated the Kendall's tau_b between performance evaluation measures (Tobin's Q and ROI) and independent variables mentioned. That is because variables are not normal. The results are indicated in table 2.

Table 2. Correlations

\begin{tabular}{|c|c|c|c|c|c|c|c|c|}
\hline & & & $\begin{array}{l}\text { Non-Executive } \\
\text { directors }\end{array}$ & $\begin{array}{c}\text { Percentage of } \\
\text { institutional } \\
\text { investors }\end{array}$ & $\begin{array}{l}\text { Capital } \\
\text { Structure }\end{array}$ & $\begin{array}{l}\text { Dividend } \\
\text { Policy }\end{array}$ & ROI & QTobin'S \\
\hline \multirow[t]{6}{*}{ Kendall's tau_b } & \multirow{3}{*}{ ROA } & Correlation & -.126 & .111 & -.384 & .119 & 1.000 & .281 \\
\hline & & Sig. (1-tailed) & $.003 *$ & .006 & .000 & .004 & . & .000 \\
\hline & & $\mathrm{N}$ & 237 & 241 & 269 & 231 & 269 & 269 \\
\hline & \multirow{3}{*}{ QTobin'S } & $\begin{array}{l}\text { Correlation } \\
\text { Coefficient }\end{array}$ & -.164 & .063 & -.058 & -.176 & .281 & 1.000 \\
\hline & & Sig. (1-tailed) & .000 & $.075 * *$ & .078 & .000 & .000 & . \\
\hline & & $\mathrm{N}$ & 237 & 241 & 269 & 231 & 269 & 269 \\
\hline
\end{tabular}

Descriptions: Table 2 shows the calculation of the Kendall's tau_b between performance evaluation measures and independent variables mentioned.

Table 2 shows that ROI has an inverse relationship with the ratio of non-executive members and capital structure, while it is directly related to the percentage of institutional investors and dividend policy. Tobin's Q is inversely related to the ratio of non-executive members and dividend policy. Simple linear regression has been employed to investigate the effect of variables on firm's performance and to find a model for the prediction of performance. 
Table 3.

\begin{tabular}{lccccccc}
\hline Independent Variable & $\mathrm{R}$ & R2adjusted & $\mathrm{F}$ & $\mathrm{Sig} F$ & $\beta$ & $\mathrm{t}$ & Sig t \\
\hline The ratio of non-executive members & 0.178 & 0.028 & 7.722 & 0.006 & -0.178 & -2.779 & 0.006 \\
The percentage of institutional investors & 0.173 & 0.026 & 7.341 & 0.007 & 0.173 & 2.079 & 0.007 \\
Capital Structure & 0.502 & 0.249 & 89.967 & 0.000 & -0.502 & -9.485 & 0.000 \\
Dividend Policy & 0.094 & 0.005 & 2.06 & 0.153 & 0.094 & 1.435 & 0.153 \\
\hline
\end{tabular}

Descriptions: Simple regression model in order to examine the relationship between independent variables with ROI

Table 3 (simple regression of ROI) shows that all examined variables except dividends policy influence on firms' performance. The most significant inverse effect is related to capital structure and the percentage of non-executive members is also negatively related to performance. The percentage of institutional investors' ownership has a direct relationship with Return on Investment.

Table 4.

\begin{tabular}{cccccccc}
\hline Independent Variable & $\mathrm{R}$ & R2adjusted & $\mathrm{F}$ & $\mathrm{Sig} F$ & $\beta$ & $\mathrm{T}$ & $\mathrm{Sig} \mathrm{t}$ \\
\hline The ratio of non-executive members & 0.241 & 0.054 & 14.492 & 0.000 & 0.241 & 3.807 & 0.000 \\
The percentage of institutional investors & 0.092 & 0.004 & 2.035 & 0.155 & -0.092 & -1.427 & 0.155 \\
Capital Structure & 0.073 & 0.002 & 1.433 & 0.232 & -0.073 & -1.197 & 0.232 \\
Dividend Policy & 0.247 & 0.057 & 14.86 & 0.000 & 0.247 & 3.855 & 0.000 \\
\hline
\end{tabular}

Descriptions: Simple regression model in order to examine the relationship between independent variables with Tobin's Q.

According to the table above, the ratio of non-executive members and dividend policy influence on firms' performance. It means that the firms' performance enhances with an increase in these variables. Multiple regressions are also employed to investigate the simultaneous effect of considered variables on firms' performance. Table 5 uses Stepwise method as the optimum solution.

Table 5. Coefficients

\begin{tabular}{|c|c|c|c|c|c|c|}
\hline & \multirow[t]{2}{*}{ Model } & \multicolumn{2}{|c|}{$\begin{array}{c}\text { Unstandardized } \\
\text { Coefficients }\end{array}$} & \multirow{2}{*}{$\begin{array}{c}\text { Standardized } \\
\text { Coefficients } \\
\text { Beta } \\
\end{array}$} & \multirow[t]{2}{*}{$\mathrm{T}$} & \multirow[t]{2}{*}{ Sig. } \\
\hline & & $\mathrm{B}$ & Std. Error & & & \\
\hline \multirow{2}{*}{1} & (Constant) & .671 & .023 & & 29.226 & .000 \\
\hline & Capital structure & -.333 & .034 & -.557 & -9.690 & .000 \\
\hline \multirow{3}{*}{2} & (Constant) & .708 & .026 & & 27.707 & .000 \\
\hline & Capital structure & -.326 & .034 & -.545 & -9.660 & .000 \\
\hline & $\begin{array}{c}\text { Non-executive } \\
\text { managers }\end{array}$ & -.001 & .000 & -.173 & -3.056 & .003 \\
\hline \multirow{4}{*}{3} & (Constant) & .707 & .025 & & 28.166 & .000 \\
\hline & Capital structure & -.334 & .033 & -.560 & -10.058 & .000 \\
\hline & $\begin{array}{c}\text { Non-executive } \\
\text { managers }\end{array}$ & -.001 & .000 & -.182 & -3.276 & .001 \\
\hline & $\begin{array}{l}\text { Dividend } \\
\text { policy }\end{array}$ & .048 & .016 & .165 & 2.968 & .003 \\
\hline
\end{tabular}

Descriptions: Multivariate regression model in order to examine the relationship between independent variables with ROI is used.

As you can see, the most significant independent variables are capital structure followed by the ratio of non-executive members and dividend policy. The ratio of institutional investors does not influence on firms' performance. 
Table 6. Coefficients

\begin{tabular}{|c|c|c|c|c|c|c|}
\hline \multirow{2}{*}{\multicolumn{2}{|c|}{ Model }} & \multicolumn{2}{|c|}{ Unstandardized Coefficients } & \multirow{2}{*}{$\begin{array}{l}\text { Standardized Coefficients } \\
\text { Beta }\end{array}$} & \multirow{2}{*}{$\mathrm{t}$} & \multirow{2}{*}{ Sig. } \\
\hline & & $\mathrm{B}$ & Std. Error & & & \\
\hline \multirow{2}{*}{1} & (Constant) & .829 & .026 & & 32.311 & .000 \\
\hline & Dividend policy & .209 & .056 & .250 & 3.739 & .000 \\
\hline \multirow{3}{*}{2} & (Constant) & .680 & .051 & & 13.305 & .000 \\
\hline & Dividend policy & .198 & .055 & .237 & 3.614 & .000 \\
\hline & Non-executive managers & .003 & .001 & .219 & 3.345 & .001 \\
\hline
\end{tabular}

Descriptions: Multivariate regression model in order to examine the relationship between independent variables with Tobin's Q is used.

The table above indicates that the most effective variables are dividend policy and the ratio of nonexecutive members, respectively. Firms' performance is not affected by other variables included. Finally, mean comparison test for two independent samples has been employed for investigating the effect of dummy variables such as the existence of institutional investors and CEO duality. The final results are reported in table 7.

Table 7.

\begin{tabular}{|c|c|c|c|c|c|c|}
\hline & & \multicolumn{2}{|c|}{ Levene's Test for Equality of Variances } & \multicolumn{3}{|c|}{ t-test for Equality of Means } \\
\hline & & $\mathrm{F}$ & Sig. & $\mathrm{t}$ & df & Sig. (2-tailed) \\
\hline ROA & $\begin{array}{l}\text { Equal variances assumed } \\
\text { Equal variances not assumed }\end{array}$ & 4.264 & .040 & $\begin{array}{l}-2.327 \\
-2.453 \\
\end{array}$ & $\begin{array}{l}245 \\
73.846\end{array}$ & $\begin{array}{l}.021 \\
.017\end{array}$ \\
\hline QTobin'S & $\begin{array}{l}\text { Equal variances assumed } \\
\text { Equal variances not assumed }\end{array}$ & 19.314 & .000 & $\begin{array}{l}-2.637 \\
-4.042 \\
\end{array}$ & $\begin{array}{l}245 \\
158.836\end{array}$ & $\begin{array}{l}.009 \\
.000\end{array}$ \\
\hline
\end{tabular}

Descriptions: Mean comparison test for two independent samples for investigating the effect of dummy variables and CEO duality

According to the table above, those companies that have institutional investors are better performers than others (considering both ROI and Tobin's Q).

Table 8.

\begin{tabular}{|c|c|c|c|c|c|c|}
\hline & & \multicolumn{2}{|c|}{ Levene's Test for Equality of Variances } & \multicolumn{3}{|c|}{ t-test for Equality of Means } \\
\hline & & $\mathrm{F}$ & Sig. & $\mathrm{t}$ & df & Sig (2-tailed) \\
\hline ROA & $\begin{array}{l}\text { Equal variances assumed } \\
\text { Equal variances not assumed }\end{array}$ & 4.264 & .040 & $\begin{array}{l}-2.327 \\
-2.453\end{array}$ & $\begin{array}{l}245 \\
73.846\end{array}$ & $\begin{array}{l}.021 \\
.017\end{array}$ \\
\hline QTobin'S & $\begin{array}{l}\text { Equal variances assumed } \\
\text { Equal variances not assumed }\end{array}$ & 19.314 & .000 & $\begin{array}{l}-2.637 \\
-4.042\end{array}$ & $\begin{array}{l}245 \\
158.836\end{array}$ & $\begin{array}{l}.009 \\
.000\end{array}$ \\
\hline
\end{tabular}

Descriptions: Mean comparison test for two independent samples for investigating CEO duality

The results reveal that these variables have no impacts on firms' performance (considering both ROI and Tobin's Q)

\section{Discussion}

The results of testing the research hypothesis are summarized as follows: 
Table 9.

\begin{tabular}{lllll}
\hline Hypothesis & Variable included & The effect on ROI & The effect on Tobin's Q & Result \\
\hline The ratio of non-executive members & inverse & inverse & Accepted \\
Ownership percentage of institutional investors & Direct & direct & Accepted \\
CEO Duality & Not significant & Not significant & rejected \\
Capital Structure & inverse & inverse & Accepted \\
Dividend Policy & direct & inverse & Accepted \\
The ownership of institutional investors & direct & direct & Accepted \\
\hline
\end{tabular}

Descriptions: The results of testing the research hypothesis.

There is an inverse relationship between the ratios of non-executive members in a board of directors and firms' performance measures which is not in consistent with the previous findings. This might be because of the weak performance of non-executive members. This is not also in consistent with the findings of Lifert.

There are some researches about corporate governance which do not verify the direct relation between the percentage of institutional investors and firms' performance measures and this is in consistent with Emam and Malek. Lanour and Al marzoughi came into a different conclusion and found that both proxies for financing decisions are related to performance measures. Capital structure measured by financial leverage has an inverse relation with the both performance measures and this shows that increased debt in capital structure leads to decreased performance. This relationship can be a reason for managements' weakness in optimum use of financial leverage and selecting a capital structure which is not suitable. Dividend policy is in direct relation with ROI while it does not hold true for the relationship with Tobin's Q. Tobin's Q can be considered as a proxy for growth opportunity and that's why decreased growth opportunities firms decide to divide more income. Capital structure variable measured by the existence of institutional investors has a direct relationship with firms' performance and this reflects the fair role of institutional investors. It should be noted that the findings about capital structure, dividend policy and the type of stockholders are in consistent with El-Mutari study.

\section{Suggestions}

Stockholders of a company that select the board of directors' members are suggested to select the managers more accurately. Non-executive members are also offered to do their operations better and more effectively.

According to the inverse relationship between capital structure and firms' performance, managers should struggle to consider the optimum use of financial leverage and capital structure. This is the case which is also mentioned for stockholders and other decision makers in performance measurement.

The findings reveal that there is a direct positive relationship between institutional investors and firms' performance. Hence this is suggested to investors to comprehend the mentioned items in their decision makings.

\section{Future Researches}

Future studies can be in different fields including investigating the effect of asymmetric environment on the selection of corporate governance mechanisms or investigating the relationship between conservatism and the type of ownership in institutional investors.

\section{References}

A, Thens. G. A., \& Lubbock. (2009). The rise of corporate governance in corporate control research. Journal of corporate finance, 15(2), 2 \&3. http://dx.doi.org/10.1016/j.jcorpfin.2008.10.002

Agnes, Lo. Raymond, M. K. Wong, \& Michael, Firth. (2010). Can corporate governance deter management from manipulating earnings? Evidence from related -party sales transactions in China. Journal of corporate finance, 16(2), 225-235. http://dx.doi.org/10.1016/j.jcorpfin.2009.11.002

Basil, Al- Najjar. (2010). Corporate governance and institutional ownership: evidence from Jordan. http://dx.doi.org/10.1108/14720701011035693

Chi, Wuchun., Liu, Chiawen, \& Wang, Taichang. (2009). What affects accounting conservatism: a corporate governance perspective. Journal of contemporary accounting \& economics, 5(1), 47-59. http://dx.doi.org/10.1016/j.jcae.2009.06.001 
Guedhami, O., Pittman, J. A., \& W, Saffar. (2009). Auditor choice in privatized firms: Empirical evidence on the role of state and foreign owners. Journal of Accounting and Economics, 48(2-3), 151-171. http://dx.doi.org/10.1016/j.jacceco.2009.08.003

Imam, M. O., \& Malik, Mahfuja. (2007). Firm performance and corporate Governance Through ownership structure: Evidence from Bangladesh Stock Market. International Review of Business.

Jayesh, Kumar. (2004). Does ownership structure influence firm value? Evidence from India, India Gandhi Institute of Development Research, India.

Jensen, M. C., \& Meckling, W. H. (1976). Theory of the Firm: Managerial Behavior, Agency Costs and ownership Structures. Journal of Financial Economics, 3(4), 305-360. http://dx.doi.org/10.1016/0304-405X(76)90026-X,

Krivogorsky, V. (2006). Ownership, board structure, and performance in continental Europe. The international journal of accounting, 41(2), 176-197. http://dx.doi.org/10.1016/j.intacc.2006.04.002

Leif, Anders Frnningen, \& Nico van der Wijst. (2009). Ownership structure and performance of the largest German companies, http://ssrn.com/abstract=1341615.

Liu, Q., \& Zhou, Lu. (2007). Corporate governance and earnings management in the Chinese listed companies: A tunneling perspective. Journal of Corporate Finance, 13(5), 881-906. http://dx.doi.org/10.1016/j.jcorpfin.2007.07.003

Mihir, A. Desaila, Alexander, Dyckb, \& Luigi, Zindalesc Ch. (2007). Theft and taxes. Journal of financial economics, 84(3), 591-623. http://dx.doi.org/10.1016/j.jfineco.2006.05.005

Siregar, S. V., \& Utama, S. (2008). Type of earnings management and the effect of ownership structure, firm size and corporate governance practices: Evidence from Indonesia. The international journal of Accounting, 43(1), 1-27. http://dx.doi.org/10.1016/j.intacc.2008.01.001

Yammeesri, j., \& Iodh, S. C. (2002). The effects of ownership structure on firm performance: Evidence from Thailand. Hawaii international conference on Business 